\title{
Osteoconstructive nanocomposite based on polyurethane with additives of polysaccharides of various origin
}

\author{
(C) Nadezhda M. Storozhok, ${ }^{1}{ }^{+}$Irina N. Tsymbal, ${ }^{1}$ Kamil R. Muratov, ${ }^{2}$ \\ Maxim R. Schukin, ${ }^{1}$ and Ivan A. Storozhok ${ }^{1}$ \\ ${ }^{1}$ Department of Chemistry, Tyumen State Medical University of the Russian Ministry of Health. \\ Odessa St., 54.Tyumen, 625023. Russia.Phone/fax: +7 (3452) 20-74-21.E-mail:nadinstor@mail.ru \\ ${ }^{2}$ Department of Analytical Physics, Tyumen Industrial University. Melnikayte St., 70. Tyumen, 625026. \\ Russia.Phone/fax: +7 (3452) 28-36-86.E-mail:kfmkd@tyuiu.ru
}

\begin{abstract}
*Supervising author; ${ }^{+}$Corresponding author
Keywords: glue, bone tissue, reconstruction, polyurethane, recinoleic acid, kryptonite, chitin, xanthan, sodium alginate, pectin, hyaluronic acid.
\end{abstract}

\begin{abstract}
The basics of chemistry and manufacturing techniques of medical bone glue based on a polymerpolyurethane matrix, in which natural polysaccharides are additionally introduced, are described. The physicomechanical characteristics of the reconstructed bones (on the model of pork ribs) are given in comparison with polyurethane without additives (kryptonite). We measured the force necessary for a longitudinal fracture of the bone at the junction, the impact force leading to the destruction of the polymer. The tests were carried out on a universal machine for tensile testing IR 5047-50, the tensile strength of which reaches $50 \times 103 \mathrm{~N}$. It is shown that, compared with the mechanical strength of kryptonite $(0.85 \mathrm{kPa})$, most polysaccharide composites are stronger from 1.2 to 2,3 times. Additives of sodium alginate and hyaluronic acid contribute to the formation of the most stable structures (2.00 MPa and 1.60 MPa, respectively). The strength of the glue with the inclusion of chitin is $1.05 \mathrm{MPa}$. The least tear resistant is the polyurethane-pectin copolymer $(0.140 \mathrm{MPa})$. The low strength of glue with pectin is explained by the features of its chemical structure, a high degree of esterification of polygalacturonic acid (84\%). Impact destruction of the material was recorded at $200 \mathrm{MPa}$, while the composite crack did not break up into fragments. Thus, the strength of new biopolymer composites is determined by the structure of polysaccharides, which increase the adhesive properties of potential medical adhesives.

Using a JSM-6510 LA scanning electron microscope from JEOL (Japan), it was shown that the composite is a cellular structure along the entire depth of the material, $70 \%$ of the polymer has pores with a size (55-160) microns. The resulting glue may be compatible with bone tissue. Osteoblasts with a size of 20$30 \mu \mathrm{m}$ can grow into the cellular structure of new materials and further increase their strength by osseointegration with the host bone. It was found that complete curing of kryptonite occurs in 75 minutes. Materials with additives of other polysaccharides can be cured in much less time (hyaluronic acid, xanthan, pectin in 15 minutes, sodium alginate in 50 minutes. The exception was chitin, which hardens in 200 minutes. During curing, the volume of all polymers increased and amounted to pectin, hyaluronic acid, xanthan gum, sodium alginate, chitin $(32 ; 50 ; 62 ; 110,250) \%$ of the initial value, respectively. Kryptonite was characterized by a $130 \%$ increase in volume. Studying the interaction of polymers with water in an isotonic solution of sodium chlorine, imitating the internal environment of the body, showed that kryptonite does not absorb water within 40 days of observation, the mass of pectin increased by $2 \%$ in 2 days, xanthan - by $5 \%$, sodium alginate - by $12 \%$, and in 40 days the mass of xanthan gum and sodium alginate increased by 12 and $24 \%$, respectively. The polyurethane composite with pectin lost $10 \%$ of its mass in the first 2 days and $35 \%$ in the next 40 days, which indicates hydrolysis of ester bonds in polygalacturonic acid. A composite with hyaluronic acid quickly absorbed water (30\% in the first 6 hours), turned into a gel and lost its adhesive properties. In air, this polymer hardens quite quickly. It is obvious that composites with hyaluronic acid can only be used in an anhydrous environment. The most promising as medical bone glue is a polyurethane-xanthan copolymer, the physicochemical properties of which (curing time 15 minutes, an increase in volume by 62\%) allow the formation of a bone bonding area and also regulate its surface during surgery. There is a direct relationship between the physicochemical properties of the new composites, the features of the primary structure, and the spatial organization of carbohydrate macromolecules. A methodological approach to the development of adhesives promising for reconstructive medicine of mineralized tissues is proposed.
\end{abstract}




\section{References}

[1] Zhang, Leilei; Li, Shaoxian; Li, Hejun; Bioactive surface modification of carbon/carbon composites with multilayer SiC-SiC nanowire-Si doped hydroxyapatite coating $J$. of Alloys and Compounds. 2018. Vol.740. P.109-117.

[2] Song, Xiaoxia; Tang, Wei; Gregurec, Danijela et al. Layered titanates with fibrous nanotopographic features as reservoir for bioactive ions to enhance osteogenesis. Applied Surease Sciense. 2018. Vol.436. P.653-661.

[3] Patent RU $2011150636 \mathrm{~A} \mathrm{Publ.} \mathrm{2013.06.20.} \mathrm{Bagramov} \mathrm{R.I.} \mathrm{Feigina} \mathrm{E.V.}$

[4] Patent RU 254332 C2. Publ. 2014.12.27 Bagramov R.I., Feigina E.V.

[5] P.A. Comeau, T.A. Willett. Alternative approach to the surface methacrylation of non-stoichiometric hydroxyapatite nanoparticles for use in bone-inspired composites. Frontiers in Materials. 2019. Vol.6. No.264.

[6] D.F. Farrar. Bone adhesives for trauma surgery: A review of challenges and developments. International Journal of Adhesion and Adhesives. 2012. Vol.33. P.89-97.

[7] Özyazgan İ. Septal Deviation Treatment Using Bone or Cartilage Grafts Fixed with Cyanoacrylate Tissue Adhesive. Aesthetic Plastic Surgery. 2017. Vol.41. P.618-627.

[8] J.S. Vieira, F.R. Santos, J.V. Freitas, F. Baratto-Filho, C.C. Gonzaga, M.R. Araujo. Bond strength evaluation of cyanoacrylate-based adhesives and screws for bone fixation. Oral and Maxillofacial Surgery. 2016. Vol.20. P.157-160.

[9] V.A. Dyatlov. Acrylamide-forming polymers: synthesis, properties and applications. Diss. Doctor of Chemical Sciences. M. 2015. 489p.

[10] I.R. Rustamova, V.A. Dyatlov, T.A. Grebeneva, A.V. Dyatlov, V.V. Zaitsevc, V.I. Maleevd. Polycyanoacrylate porous material for bone tissue Substitution. J. Mater. Chem. 2014. Vol.2. P.43104317.

[11] Fedak, Pol U. M., T.M. Kieser, E.M. Meytlend et al. Uluchshennoye kleykoye naruzhnoye zakrytiye dlya uluchsheniya posleoperatsionnogo funktsional'nogo vosstanovleniya: pilot, randomizirovannoye kontroliruyemoye issledovaniye. Annaly Torichescoy khirurgii. 2011. Vol.92. No.4. P.1444-1450.

[12] Nuzzo G. Luongo M., Parlato C. et alReconstruction Using Bioabsorbable Calcified Triglyceride Bone Cement. J. Craniofacial Surgery. 2010. Vol.21. No.4. P.1170-1174.

[13] J. Kucinska-Lipka, I. Gubanska, O. Korchynskyi. The Influence of Calcium Glycerophosphate (GPCa) Modifier on Physicochemical, Mechanical and Biological Performance of Polyurethanes Applicable as Biomaterials for Bone Tissue Scaffolds Fabrication. Polymers. 2017. Vol.9. No.8. P.329.

[14] T.S. Seregina, V.R. Ivanova, V.G. Kharitonova, I.A. Derevnin, V.V. Zaitsev, V.A. Dyatlov. Synthesis of polymer biological tissue modifiers containing aminglicoside antibiotics. Advances in Chemistry and Chemical Technology. 2018. Vol.XXXII. P.24-26.

[15] F. Qin, X.M. Chen, Y.Q. Liu. Improved procedure for preparation of covalently bonded cellulose trisphenylcarbamate chiral stationary phases. Chine Journal of Chemistry. 2005. Vol.23. No.7. P.885-890.

[16] F. Cedano, S. Ayala, M. Caicedo, A. Mendoza, J. Casas, C. Castro, D. Tabima, J. Moreno, J. Briceno. Formulation, preparation and characterization of a bone adhesive. Pan American Health Care Exchanges Conference (PAHCE). 2013. Medellin, Colombia. org. /1109/PAHCE,2013.6568222.

[17] S. Zhao, Z. Wang, H. Pang, Z. Li, W. Zhang, S. Zhang, J. Jianzhang Li, L. Li. Designing Biomimetic Microphase-Separated Motifs to Construct Mechanically Robust Plant Protein Resin with Improved Water-Resistant Performance. Macromolecular Materials and Enginering. 2020. //doi.org/10.1002/mame.201900462/

[18] Z. Zheng, Ch. Tsui, J. Si. Modification of three-dimensional porous composite frameworks of hydroxyapatite and thermoplastic polyurethane to enhance interfacial adhesion using a polydopamine surface coating. ACS OMEGA. 2019. Vol.4. No.4. P.6382-6391.

[19] D. Lu, H. Wang, X. Wang. Biomimetic chitosan-graft-polypeptides for improved adhesion in tissue and metal. Carbohydrate polimers. 2019. Vol.215. P.20-28.

[20] Y. Huanhuan, L. Linlong, W. Zongliang, W. Yu, G. Min, S. Xincui, Y. Jui-Ming, Z. Peibiao. MusselInspired Conducting Copolymer with Aniline Tetramer as Intelligent Biological Adhesive for Bone Tissue Engineering. ACS Biomater. Sci. Eng. 2020. Vol.6. No.1. P.634-646.

[21] V.S. Balabaev, I.A. Glotova, V.N. Izmailov. The manufacturability of alternative raw materials for food chitosan. Modern problems of science and education. 2015. No. 1-1.; http://www.science-education.ru.

[22] P. Fedak, E. Kolb, G. Borsato, E.C. Frohlich, A. Kasatkin, K. Narine, N. Akkarapaka, K. King. Kryptonite Bone Cement Prevents Pathologic Sternal Displacement. The Annals of Thoacic Surgery. 2010. Vol.90. No.3. P.979-985.

[23] N.M. Storozhok, M.R. Schukin, K.A. Leontiev, I.A. Storozhok, K.R. Muratov. Physicochemical fundamentals of creating a new generation of medical glue In sb. III international conference "Modern 

achievements in the field of a dhesives and sealants: materials, raw materials, technologies". Nizhny Novgorod. 2019. P.57-59.

[24] Storozhok N.M., Schukin M.R., Leontyeva K.A. A new generation osteoconstructive calciumcontaining nanocomposite with polysaccharide additives. In the materials of the Congress "Man and Medicine Ural-2019". Tyumen. 2019. P.85-86.

[25] I.A. Kukin, I.V. Kirpichev, L.B. Maslov, S.V. Vikhrev. Features of the strength characteristics of the cancellous bone in diseases of the hip joint. Fundamental Research. 2013. No.7(2). P. 328-333.

[26] M. Figurska. The structure of compact bone tissue. Russian Journal of Biomechanics. 2007. Vol.11. No.3. P.28-38.

[27] G.D. Doumit, E. Meisler, J. Sidaoui, J.E. Zins, F.A. Papay. The Expansile Properties of Kryptonite Relating to Cranioplasty. Journal of Craniofacial Surgery. 2014. Vol.25. No.3. P.880-883. 